\title{
VYBRANÉ ASPEKTY APLIKÁCIE METÓD PRINCE2 A MSP V PROJEKTOVOM A V PROGRAMOVOM MANAŽMENTE
}

\author{
Lubomír Bombala, Viera Majerčíková*
}

Úvod

Za hlavný dôvod, prečo sa chceme venovat' aplikácii metód v projektovom a programovom manažmente, považujeme niektoré nepresnosti, ku ktorým dochádza pri uplatňovaní týchto metód. Dobrým príkladom takéhoto problému je aplikácia metódy PRINCE2 $\mathrm{v}$ projektovom manažmente. Za jeden $\mathrm{z}$ podstatných problémov pri aplikácii PRINCE2 považuje Richard Rose, certifikovaný školitel' z Pearce Mayfield, problém súvisiaci s požiadavkou PRINCE2 na riadené prostredie $\mathrm{v}$ organizácii, ktorá chce metódu implementovat'. Metóda sama nestačí, jej aplikácia kladie požiadavky aj na prostredie, v ktorom sa má aplikovat'.

Dôležitou motiváciou pre tento príspevok bol náš ciel' upozornit' na rozdielnost' oboch metód, ich špecifický účel a spoluprácu pri dosahovaní zmien v organizáciách. V oblasti použitej terminológie chceme nadviazat' na publikované príspevky o metódach PRINCE2 [1] a MSP [2].

\section{Definovanie projektov a programov v organizáciách}

Častým problémom vyskytujúcim sa v prostredí organizácií i počas interných auditov je otázka toho, čo možno resp. nemožno pokladat' za projekt? Množstvo práce, ktorá sa vykonáva v podnikovom prostredí sa pokladá za „štandardnú činnost'“, hoci vyžaduje množstvo zdrojov a je oznamovaná mnohým komisiám a radám v rámci organizácie, čo vedie k názoru, že l'udia, ktorí sa ich zúčastňujú, sú súčast'ou projektov. projektov [3]:

Colin Bentley, hlavný skúšajúci PRINCE2, v tejto súvislosti uvádza niektoré definície

PRINCE2 definuje projekt ako [8]:

\footnotetext{
* Ing. Lubomír Bombala, DHL IT Services Europe, V Parku 2308/10, 14800 Praha 4, ext. doktorand, Katedra spojov, FPEDAS, ŽU v Žiline

tel: +420288802185

e-mail: lubomir.bombala@dhl.com

Ing. Viera Majerčíková, KIMEA, s.r.o. , Ulica republiky 30, 01001 Žilina, ext. doktorandka, Katedra

ekonomiky, FPEDAS, ŽU v Žiline

tel: +421949365793

e-mail: vierka.ziakova@gmail.com
} 
„riadené prostredie vytvorené za účelom poskytnutia jedného alebo viacerých produktov podnikania na základe špecifického podnikatel'ského prípadu."

Ďalšia definícia projektu môže byt’ [3]: „dočasná organizácia, ktorá je potrebná na vytvorenie jedinečného a preddefinovaného výstupu alebo výsledku v dopredu špecifikovanom čase použitím dopredu determinovaných zdrojov.“

PRINCE2 navyše predpokladá, že tí, ktorí sú zodpovední za projekt, nemusia mat' skúsenost' z práce spolu za účelom vytvorenia podobného súboru výstupov alebo výsledkov pre toho istého zákazníka z minulosti, že koordinácia medzi tými, čo pracujú na projekte, musí byt' dobre organizovaná a zodpovednosti zdiel'ané a jasne definované medzi tými, ktorí vykonávajú prácu, ktorí ju manažujú a tými, ktorí ju sponzorujú (financujú).

PRINCE2 nerozlišuje medzi projektmi, čo sa týka vel'kosti, rozpočtu a pod. Dá sa prispôsobit' akejkol'vek vel'kosti projektu.

PRINCE2 projekt má nasledovné charakteristiky [3]:

- konečný a definovaný životný cyklus

- definované a meratel'né produkty podnikania

- korešpondujúci súbor aktivít na dosiahnutie produktov podnikania

- definované množstvo zdrojov

- organizačnú štruktúru s definovanými zodpovednost’ami týkajúcimi sa riadenia projektu.

Tony Kippenberger, redaktor pm4success, $v$ tejto súvislosti prináša vlastný pohl'ad [3]: „ „projekt nie je projektom“, ked' je to skôr rutinná podnikatel’ská činnost' ako jedinečná úloha (a to aj v prípade, že vel'a projektov je podobných).”

Každý projekt spadá do špecifického podnikatel'ského kontextu. Projekt môže byt' samostatný, môže byt' jedným v sekvencii súvisiacich projektov alebo môže byt' súčast'ou programu alebo korporátnej stratégie. Svojou povahou predstavuje dočasnú štruktúru, vytvorenú s ciel'om dosiahnut' špecifikovaný podnikatel'ský prínos alebo účel. Ked' sa dokončí práca na projekte, tak sa projekt rozpadne. Mnohé dostupné zdroje (vrátane the Bodies of Knowledge) ponúkajú vlastnú definíciu pojmu projekt.

Alan Harpham, predseda APM Group, ako skúsený odborník s praxou v oblasti projektového manažmentu uprednostňuje dlhšiu definíciu projektu a definuje projekt nasledovne [3]:

„Projekt možno najjednoduchšie popísat' ako jedinečnú úlohu alebo jednorazovú aktivitu, skôr ako bežné operácie zo dňa na deň alebo „štandardnú podnikatel'skú činnost““. Odlišným ho robí fakt, že má dátum začiatku a dátum konca. Ale má tiež množstvo d'alších znakov. Projekt je jednorazová aktivita, ktorá:

- má začiatok a koniec

- má jasný účel

- bude využívat' zdroje, napr. vyžaduje čas, peniaze a zapája skupinu l’udí

- bude komplexný napr. skupina medzi sebou previazaných úloh zapájajúc množstvo l'udí, ktorí musia byt' informovaní o tom, čo majú urobit' za časový interval

- bude prechádzat' sériou sekvenčných fáz s životným cyklom

- bude dodávat' výstup, ktorý môže vlastník použit' na dosiahnutie požadovaného výsledku pre organizáciu.“

Alan Harpham k tejto definícii dodáva [3]:

„Samozrejme, že mnohé aktivity splńajú mnohé zo zoznamu kritérií projektu. V mnohých organizáciách sa centralizovane uskutočňuje rozhodnutie, kedy aplikovat' s úplnou prísnost'ou projektový manažment na projekty, a preto sa zohl'adňuje vel'kost', rozsah, komplexnost', dôležitost' výsledku pre organizáciu. Samozrejme, že jeden môže aplikovat' projektový manažment na vel'mi malé projekty, vrátane, ako som raz počul povedat' jedného lektora, „prípravy šálky čaju“. Avšak faktom zostáva, že hoci príprava šálky čaju 
zahŕňa viac ako jednu aktivitu, nie je obyčajne pokladaná za dost' komplexnú alebo dost' dôležitú, aby sa považovala za projekt.

Determinovanie toho, čo možno považovat' v organizácii za projekt vyžaduje úsudok a triezve uvažovanie - vel'mi malý projekt a l'udia budú vidiet' projektový manažment ako byrokraciu na vrchole jednoduchých aktivít, vel'mi vel'ký projekt a môžu sa vyskytnút' závažné problémy $\mathrm{v}$ investičnom programe organizácie. Neexistujú žiadne univerzálne pravidlá pre determinovanie toho, čo organizácia nazve projektom.”

V prostredí organizácií je takisto potrebné rozlišovat' medzi work package, projektom a programom $[1,2]$. termínmi [3]:

Colin Bentley ponúka nasledovné definície na rozlíšenie medzi spomenutými tromi

„Work package je definovaná čast’ práce v rámci projektu alokovaná individuálom alebo tímu. Nemá žiadny podnikatel'ský prípad a jej požiadavky na kvalitu sú definované v kópiách relevantných popisov produktov.

Projekt má podnikatel'ský prípad a obsahuje celý rad work packages, ktoré pomáhajú naplnit' ciele projektu. Podnikatel'ský prípad je nastavený tak, aby podporoval podnikatel'ský prípad programu.

Program pozostáva z určitého množstva projektov a má podnikatel'ský prípad. Jeden typ programu môže byt' iba zoskupením projektov pod jedným rozpočtom alebo pre jedného zákazníka, projekty nemajú žiadne d'alšie prepojenie navzájom. Ďalší typ programu môže byt' strategický, v ktorom všetky projekty prispievajú k dosiahnutiu hlavnej podnikatel'skej zmeny, ale môžu prebiehat' v rozličných časoch."

Väčšina organizácí́ sa zameriava na dlhodobé strategické ciele. Stratégie, ktoré ich vedú v ústrety týmto ciel'om, sú navrhnuté tak, aby flexibilne reagovali na faktory, ktoré znamenajú nové smerovanie, sú to „nosiče zmeny“ [4].

V organizácii bude fungovat' mnoho nosičov zmeny. Budú sa líšit' v povahe a naliehavosti, od externých tlakov ako sú konkurenčné trhy alebo zmeny v legislatíve k interným tlakom, ako sú nové pracovné usporiadanie vyplývajúce z fúzií a akvizícií. V organizáciách budú existovat' aj nosiče stability, ktoré odmietajú zmeny, podporujú nečinnost' a niekedy robia rozhodnutia zložitejšími [4].

Naplnenie stratégie a teda reagovanie na nosiče vyžaduje uskutočnenie množstva výhodnejšie menšieho množstva - programov. Stratégia nastavuje kontext pre zmenu a poskytuje prvotný materiál na plánovanie, organizovanie a dokončovanie programov. Programový manažment je dodaním zmeny vo forme výsledkov, a tým aj prínosov. Je to rámec pre implementovanie podnikatel'ských stratégií, postupov a iniciatív alebo zmeny vel'kého rozsahu v rámci celkovej vízie želaného výsledku [4].

Programový manažment je štruktúrované rozhranie pre definovanie a implementovanie zmeny v organizácii. Program predstavuje portfólio projektov a aktivít, ktoré sú koordinované a manažované ako celok, takže ich výstupy a prínos majú strategický význam pre organizáciu. Programový manažment je o manažovaní nejasností. Nejasnosti sa objavujú, ked' cesta dosiahnutia vízie nie je jasná na začiatku alebo pokial' sa cesta dosiahnutia vízie upravuje počas realizácie programu alebo ked’ dôjde k tomu, že samotná vízia vyžaduje vylepšenie [6].

Vo svetle definícií projektového a programového manažmentu sa môžeme bližšie oboznámit' s výhodami, ktoré pre organizácie prináša uplatnenie programového manažmentu $[5,7]$ :

- medzera medzi stratégiami a projektmi je vyplnená

- formálny proces na identifikovanie, manažovanie, realizáciu a meranie prínosov

- manažmentový rámec, ktorý sa sústredí na ciele zmeny v podnikaní

- efektívny manažment podnikatel'ského prípadu, aby sme dosiahli víziu 
- jasné zodpovednosti za prípravu na implementáciu zmeny v podnikaní

- širší kontext rizík je lepšie pochopený

- dobrý manažment kontroly nákladov

- projekty sú prioritizované a integrované, aby manažovali zdroje lepším spôsobom

- koordinácia a riadenie komplexnej škály činností

\section{Úloha projektových a programových manažérov}

V súvislosti s projektovým manažmentom považujeme za dôležité upozornit’ aj na niektoré rozdiely v porovnaní s vertikálnym (priamym) manažmentom.

Colin Bentley upozorňuje na niektoré rozdiely týkajúce sa práce projektového resp. programového manažéra a vertikálneho manažéra [3]:

„Projektový manažér a tiež programový manažér musí informovat' a vyhoviet' viacerým nadriadeným napr. projektovej rade, zúčastneným stranám; vertikálny manažér normálne reportuje iba jednému manažérovi.

Projektový manažér musí mat' detailnú, aktuálnu informáciu o všetkom, čo sa deje v projekte; vertikálny manažér má často svojich podriadených zapojených do mnohých projektov a zaujíma sa iba o to, kedy začnú a kedy budú dostupní pre d’alšiu prácu.

Projektový manažér je zaviazaný dosiahnutiu ciel'ov projektu, vertikálny manažér nie. Projekt je jedinou prioritou projektového manažéra; vertikálny manažér bude mat' vela odlišných priorít.

Programový manažér je zodpovedný, v zastúpení Senior Responsible Owner (SRO), za úspešné dodanie požadovanej zmeny. Jeho úloha si vyžaduje efektívnu koordináciu projektov, ich vzájomných závislostí a akýchkol'vek rizík a problémov, ktoré môžu nastat'. Vo väčšine prípadov sa programový manažér sústredí vo svojom pracovnom zaradení výlučne na program, pretože jeho úloha je kritická pre vytvorenie a udržanie entuziazmu.

Programový manažér je zodpovedný za hladký priebeh prác na programe, manažovanie rizík, problémov, zdrojov, komunikácie, atd’. predovšetkým využívajúc poznatky projektových manažérov a úzko spolupracujúc s BCM.”

Z hl'adiska organizačného usporiadania metódy PRINCE2 a MSP vel'mi jasne definujú zodpovednosti a právomoci jednotlivých členov projektového či programového tímu.

Programový manažér je zodpovedný za celkovú integritu a koherenciu programu, vyvíja a udržuje programové prostredie, aby tak podporoval každý jednotlivý projekt, ktorý je súčast'ou programu - typicky prostredníctvom funkcie programme office.

Aká sú teda možnosti programového manažéra, čo sa týka množstva projektov, ktoré môže riadit?

Andy Taylor, hlavný skúšajúci v MSP, upozorňuje na viacero faktorov, ktoré ovplyvňujú možnosti programového manažéra [3]:

„Odpoved' bude závisiet' na viacerých faktoroch, ktoré sa musia brat' do úvahy vo svetle organizácie, zapojených l'udí, projektoch a programe. Pod'me sa nimi postupne zaoberat'.

Organizácia musí byt' schopná zabezpečit' použitie štruktúrovaných riadiacich metód, ak sa majú PRINCE2 a MSP používat’ efektívne. Často sa používajú slová „zhodný s“ alebo aspoň „,V súlade“ so systémami. Pokial” tomu tak nie je, žiadne množstvo programového alebo projektového riadenia nepomôže a odpoved' by bola, že v rámci programu môže byt' iba vel'mi málo projektov.

Ak je organizácia vo vel'mi dobrej zhode s týmito metódami, potom môže toho realizovat' viac s vedomím, že organizácia bude viac pomáhat' ako brzdit' beh programov a projektov. 
Ludia angažovaní do činností musia byt' kvalifikovaní a skúsení. Čím je program väčší, tým viac skúseností budú potrebovat'. Č́m viac projektov chcú realizovat' v rámci programu, tým väčšie sú aj na nich kladené požiadavky, a toto je tiež reflektované v schopnostiach, znalostiach a skúsenostiach projektových manažérov v rámci programu. Ak majú projektoví manažéri vel'a skúseností, potom môže byt' v rámci jedného programu viac projektov.

Povaha projektov má tiež svoje opodstatnenie. Vel'mi jednoduchý, priamočiary, ale rozsiahly súbor malých projektov sa bude realizovat' ako program podstatne l'ahšie ako súbor niekol'ko vel'mi komplexných projektov. V niektorých prípadoch môže program pozostávat' iba z jedného projektu, ale zdá sa rozumné z dôvodov definovaných v MSP, aby sa realizoval v rámci programu.

Rozhodnutie spustit' program namiesto projektu by malo byt' vykonané z dobrých strategických dôvodov a MSP poskytuje k tomu potrebné rady.

Alan Harpham uvažuje nad tým, čo ovplyvňuje rozhodnutie spustit' program [3]:

„Závisí na povahe, množstve, načasovaní a kritickosti každého projektu v rámci programu a pravdepodobne niekol'kých d'alších kritérií, ktoré som v tomto okamihu neuvažoval. Tiež to závisí na kvalite a skúsenosti programového manažéra a jeho projektových manažérov.“

Alan Harpham upozorňuje na to, že je vel'mi t’ažké poskytnút' precíznu odpoved', a preto uviedol konkrétny príklad [3].

„Ak má programový manažér viac ako povedzme 6 až 7 zaneprázdnených projektových manažérov a každý z nich má jeden alebo dva dôležité projekty bežiace súčasne v obtiažnej fáze (definícia a plánovanie alebo začiatok implementácie), je pravdepodobne na hranici svojich možností, a to aj v prípade primerane skúseného programového manažéra.“

Vzhl'adom na to, že možnosti projektového manažéra sú tiež obmedzené, môžeme sa zaoberat' obdobnou otázkou, kol'ko projektov môže manažovat' a čo to ovplyvňuje?

Colin Bentley v tejto súvislosti uviedol [3]: „Toto závisí na vel'kosti, komplexnosti, kritickosti a riziku spojenom s projektmi. Existujú však približné odhady. Ked’ má projekt viac ako dva tímy alebo 15 členov, viac ako jednu geografickú lokalitu, vyžaduje si projektového manažéra, ktorý sa projektu venuje výhradne. Ak sú projektové tímy malé a majú skúsených tímových vedúcich, projektový manažér môže úspešne manažovat' aj tri projekty. Ak má projektový manažér manažovat' viac ako jeden projekt, mal by mat' dostupnú podporu od skúseného pracovníka na pozícii Project Support. Ak sú s projektom problémy alebo je blízko tolerancie z hl'adiska času, nákladov alebo kvality, bolo by nerozumné, dat' ho projektovému manažérovi, ktorý sa mu nemôže venovat' úplne.“

Ďalšiu dôležitú oblast' predstavujú otázky kompetencií, kvalifikácie a výberu projektových a programových manažérov.

Odkial' máme vybrat' vhodného kandidáta na post programového manažéra? Mal by byt' na post programového manažéra menovaný zástupca zákazníka pre sadu projektov alebo je programový manažér z organizácie, ktorá dodáva projekty?

Colin Bentley vyjadril očakávanie, že programový manažér je menovaný zo strany zákazníka [3].

Avšak Andy Taylor zvažuje alternatívy [3]: „Môj pohl'ad na toto nie je vel'mi jasný a nemá ho ani samotné MSP. MSP hovorí, že programový manažér pracuje v zastúpení SRO, a to naznačuje, že obyčajne sú z rovnakej organizácie - podnikania, ktoré vyžaduje, aby bola dodaná zmena.

Avšak, ak je určitý počet projektov dodávaný jednou organizáciou, môže byt' pre programového manažéra vhodnejšie, aby pochádzal zo strany tejto organizácie. Som trochu znepokojený, že podnikanie v tomto scenári stratí kontrolu nad programom. Pokial' má 
organizácia vhodné riadiace prostriedky, aby mohla riadit' smerovanie a vývoj programu, nevidím problém $\mathrm{v}$ ani jednej z alternatív.”

V súvislosti s projektovým manažmentom v niektorých technických oblastiach sa často objavuje otázka, do akej miery by mal mat' projektový manažér skúsenosti z oblasti, v ktorej manažuje projekty a do akej miery to ovplyvňujú podmienky projektu?

Colin Bentley v súvislosti s kvalifikáciou projektových manažérov uvádza nasledovné [3]: „V prostredí mnohých spoločností sú na posty projektových manažérov vyberaní zamestnanci s technickou znalost'ou predmetu projektu, ale bez znalostí metód PRINCE2. Nedostatok projektových znalostí sa potom rieši tak, že skúsení projektoví manažéri sú priradení na rôzne projekty ako poradcovia projektových manažérov v otázkach aspektov projektového manažmentu."

Richard Pharro, riaditel' APMG, ktorý disponuje značnou skúsenost'ou v tejto oblasti, ponúka nasledovné úvahy [3]: „Toto je stále sa opakujúca otázka, na ktorú neexistuje úplná odpoved', pretože do vel'kej miery závisí na prostredí, v ktorom sa projekt realizuje.

Ak je projekt vel'kou investíciou pre podnikanie, potom by sme mali chciet' manažéra so skúsenost'ou s úspešným dodaním niečoho podobného, takže by mal technické znalosti z oblasti projektu.

Ak je to malý projekt $\mathrm{v}$ rámci portfólia spoločnosti, tak by mohol byt' manažovaný skúseným projektovým manažérom ako súčast' rozvoja jeho znalostí.

Ak ste zostavili skúsený profesionálny tím (odborníci, inžinieri), budete manažovat' tím, tím zabezpečí technológiu, takže pokial' sú požiadavky projektu jasné a nemusíte sa príliš zaoberat' nákladmi a časom, máte dobré tolerancie a podporujúcu projektovú radu, mal by to zvládnut' dobrý projektový manažér.

Ak organizácia nemá skúsenosti s podobnými projektmi a nejasnosti spojené s takýmto projektom sa jej zdajú nepríjemné, mali by na post projektového manažéra ustanovit' niekoho so skúsenost'ou s dodaním podobných projektov, takže bude schopný „školit' a usmerňovat'“ projektovú radu.

Ak vymenujeme projektového manažéra s množstvom technických znalostí, ale nedostatkom znalostí projektového manažmentu, môžeme sa dostat' do horšej situácie, ako majúc dobrého projektového manažéra bez technických znalostí, pretože technický expert sa bude chciet' „pohrat"“ s technickým riešením.“

V súvislosti s vytvorením programu a začlenením projektov do programu a ustanovením projektových a programových manažérov sa môže vyskytnút' otázka, či je programový manažér ich vertikálnym manažérom. Z pohl'adu PRINCE2 manuálu sa projektoví manažéri zodpovedajú projektovej rade [8].

Andy Taylor v súvislosti s týmto problémom vyjadril presvedčenie [3]:

„Otázka vertikálneho manažmentu projektových manažérov patrí medzi tie, ktoré vedú k diskusii. Môj pohl'ad je, že by mali byt' manažovaní programovou, resp. projektovou organizáciou, a to by mohlo znamenat' programového manažéra. Alternatívne by mohli byt' manažovaní projektovou radou - konkrétne jej členom v pozícii Executive. S touto situáciou by som nebol príliš nespokojný. Čo je určité jasné, je fakt, že musia byt' manažovaní niekým, kto rozumie ich práci, aby tak zaistil, že sú správne hodnotení, trénovaní, povýšení atd'.“

Ďalším doporučením je, že by mali byt' riadení osobou z oblasti podnikania, v ktorej sa projekt realizuje. K tejto alternatíve Andy Taylor uviedol [3]: „Toto sa mi zdá menej uspokojivé, pretože vertikálny manažér nemusí byt' dostatočne oboznámený s prácou projektového manažéra, a preto nemusí byt' schopný pomáhat' a podporovat' spôsobom očakávaným od dobrého vertikálneho manažéra.”

\section{Aplikácia metód PRINCE2 a MSP}


Medzi dôležité aspekty úspešnej aplikácie metódy PRINCE2 zarad’ujeme prostredie organizácie. Pokial' máme na mysli štátnu organizáciu, akou môže byt' napríklad ministerstvo obrany, je vel'mi zložité vytvorit' prístup zaručujúci právomoci projektovej rady a projekt je často riadený a vedený na operačnej úrovni.

$\mathrm{Na}$ tento problém upozorňuje aj Colin Bentley [3]: „Manažovanie zdola nahor napokon môže priniest' problémy. Nikdy by ste nemali dat' senior manažmentu šancu povedat': „Nič som o tomto nevedel” alebo „Nemal si právo to urobit“", pretože ak sa projekt dostane do problémov a budú kontaktovaní s otázkami, bude to nakoniec zlyhanie projektového manažéra. Musíte mat' klienta pre projekt a niekto musí byt' zodpovedný za alokovanie zdrojov pre projekt. V mne známom prípade, kde bolo PRINCE2 zavedené zdola nahor z úrovne projektového manažmentu, senior manažment neveril projektovej rade, pretože ich na tú funkciu nestanovil, takže každý end stage report a požiadavka na schválenie si vyžiadala mesiace, kým prešli schválením.”

V súvislosti s implementovaním metódy PRINCE2 do existujúcich projektov môžeme citovat' Colina Bentleyho [3]:

„Najlepšou metódou zavedenia PRINCE2, ktorú sme našli, je využitie health check formulárov na konci PRINCE2 manuálu ako kontrolný zoznam pre „dotazovanie“ projektových manažérov súčasných projektov, ktoré nevyužívajú PRINCE2. Projekty by mali byt' porovnané vzhl'adom na health check a vzhl'adom na status projektu (napr. ak existujú evidentné problémy so spíňaním termínov, začnite s pohl'adom na to, ako boli vykonané procesy Riadenie zmien a Plánovanie).

Za normálnych okolností každý projekt môže byt' overený, aby sme videli:

(a) ako zodpovedá každému komponentu PRINCE2, využitie procesov, využitie techník a (b) v akom statuse je projekt v rámci každej oblasti. Je potrebné začat' s oblast’ami, ktoré sú v zlom statuse a stanovit' ciel' pre dostanie projektu do súladu s PRINCE2 metódami v týchto oblastiach. Napríklad, ak sú problémy s tým, kto má aké zodpovednosti, dajte týždeň na to, aby si tím projektového manažmentu zorganizoval popisy práce a podpísal ich, potom sa presuňte na d'alšiu oblast'.

Môže existovat' množstvo krokov, ktoré bude potrebné vykonat', aby sme dostali projekt do súladu s PRINCE2. Začnite s väčšími projektmi alebo tými, ktoré majú problémy. Neimplementujte čast' PRINCE2 iba kvôli metóde. Sústred’te sa na čast' PRINCE2, ktorá môže zlepšit' riadenie projektu.“

Napriek obrovskému úsiliu organizovat' prácu v organizáciách či už v štátnom alebo privátnom sektore do projektov, môže existovat' skupina skeptikov, ktorí vnímajú metódu, ako nárast administratívy a papierovania. Colin Bentley $\mathrm{v}$ tejto súvislosti hovorí [3]: "Problémom s týmito skeptikmi je, že nemyslia na to, čo sa skrýva za slovom „správa”. Ak čítajú PRINCE2, uvedomia si, že správa môže byt' verbálna, emailová alebo písaný dokument. Celé to závisí na potrebách projektu. Ak sa pozriete na informácie v týchto správach, verím, že každý projektový alebo senior manažér by povedal, že je to informácia, ktorú chceli. PRINCE2 poskytuje rady o tom, kedy by sa to malo vykonat', projektová rada a projektový manažér rozhodnú o médiu na výmenu informácií. Podobne hodnotenie sa nemusí vykonávat' na formálnych mítingoch. Môže byt' dohodnuté, že telefónne rozhovory alebo emaily sú dostatočné pre niektoré typy mítingov. Znova je to iba otázka rozhodnutia projektovej rady a projektového manažéra, čo je najlepšie pre projekt.““

V prípade, že organizácia zamýšl'a vel'ké množstvo aktivít, ktoré vykonáva formou metódy priameho dodania previest' na projekty, je na mieste otázka, či pri prechode na projektový manažment s využitím PRINCE2 možno tieto projekty realizovat' v rámci programu alebo radšej ako oddelené nepreviazané projekty?

Colin Bentley uviedol [3]: „Bez poznania detailov projektov by sme ich mohli pokladat' za program. Program sa bude zaujímat' o podnikatel'ský prípad a celkové 
načasovanie a alokáciu zdrojov. Projekty sa zdajú byt' založené na jednom generickom modeli, ktorý by mal byt' opakovatel'ný pre viac projektov. Zdalo by sa rozumné, aby existovala šablóna pre Project Mandate alebo Project Brief pre všetky projekty. Aj produkty ako Project Plan môžu byt' opakovane použité.“

Andy Taylor upozorňuje na to, že situácia je ovplyvnená tým, či sa jedná o jednotlivý projekt opakovaný $\mathrm{v}$ rôznych časoch alebo aspoň s rozličnými zdrojmi, alebo všetko má byt' implementované v rovnakom čase s jedným tímom zdrojov [3]: „Vôbec si nie som istý, či je nejakým prínosom zat'aženie organizácie s dodatočnými komplikáciami MSP, pokial' celkový prínos je vel'mi dobre definovaný a rozsah dost' limitovaný.“

Colin Bentley je presvedčený o tom, že realizovanie projektov ako súčast' programu by bolo užitočné. Andy Taylor sa zaoberá tým, či prínosy z realizácie programu budú schopné vyvážit' prácu naviac spojenú s realizáciou programu nad projektmi. Pre konečné rozhodnutie sú dôležité konkrétne okolnosti v rámci organizácie.

Pri zavádzaní metód sa nám nepodarí vždy zaviest' všetky elementy MSP. Andy Taylor upozorňuje na najdôležitejšie elementy MSP [3]: „Podotkol by som, že celé MSP je dôležité, ale rovnako ako PRINCE2 by sa malo uplatňovat' rozumne. Z môjho pohl'adu sú kritické blueprint a definícia programu. Definujú program vo všetkých ohl'adoch. Governance je známa ako oblast', kde programy najčastejšie zlyhávajú. Takže je vhodné ju zvolit' ako čast' procesu. Moje osobné presvedčenie je, že ak nedefinujete a nemanažujete podnikatel'ské prínosy, má malý význam robit' niečo zo zvyšku MSP. Ak dodávanie podnikatel'ských prínosov nie je ciel'om programu, prečo ho vlastne robíte?

Využitie procesov $\mathrm{v}$ transformačnom toku je naozaj otázkou vol'by. Ak už máte program, potom pravdepodobne už manažujete tranže a máte projektových manažérov riadených využitím Delivering the Capability. Realizing the Benefit, ako bolo už spomenuté, je pravdepodobne úsek, ktorý nevykonávate a nemá cenu ho zvažovat' vel'mi seriózne. Ak sa program práve vyvíja, kombinácia Identifying a Programme a Defining a Programme sú pravdepodobne hodné úsilia dodat' produkty s lepšou kvalitou.“

\section{Porovnanie metód pre projektový a programový manažment}

V súvislosti s rozdielmi medzi projektovým a programovým manažmentom môžeme citovat' Andyho Taylora [3]: „Od projektov sa vyžaduje, aby dodali špecifické veci (výstupy alebo produkty), či už sú hmatatel'né (dom, počítačový systém) alebo nehmatatel'né (zmena kultúry, imidž). Očakáva sa, že budú dodané načas, v rámci nákladov a v požadovanej kvalite, a potom budú projekty rozpustené.

Programy obsahujú množstvo projektov dodávajúcich svoje produkty alebo výsledky spolu s inými neprojektovými činnost’ami za účelom dodania prínosov zo zmien uskutočnených projektmi. Budú rozpustené, ked' bude zrealizované dostatočné množstvo prínosov, a toto sa stane pravdepodobne krátko potom, ako sa uzavrie posledný projekt.

Vo všeobecnosti projekty vytvárajú produkty, ktoré sú kombinované, aby vytvorili schopnost', ktorá je potom uvedená do prevádzky a dodáva výsledky (zmenu), ktorá je meraná prínosmi.“

Porovnanie rozličných metód pre projektový a programový manažment je zložitý proces, ešte zložitejší sa zdá, ked' si uvedomíme, že existujú aj lokálne kvalifikácie v tejto oblasti. Tony Kippenberger k porovnaniu metód uviedol [3]: „Vytvorit' porovnanie medzi rozličnými metódami a kvalifikáciami je vel'mi problematické a zriedka jednoduché. Zatial' čo samozrejme existujú dobre zavedené lokálne kvalifikácie (napr. the Australian Institute of Project Management’s Registered Project Manager - RegPM), tlak globalizácie a potreba práce projektových manažérov v zahraničí spôsobili, že existujú tri kvalifikácie, ktoré sú čoraz viac medzinárodné. 
To znamená, že porovnanie dosiahnutej úrovne v rámci príslušnej kvalifikácie je relatívne l'ahké, čo je ale komplikovanejšie, je porovnanie jednej kvalifikácie s inou. Jedna je založená na kompetenciách (IPMA), jedna je založená na zoskupení poznatkov (PMI) a jedna je založená na metodológii (PRINCE2). Takže napr. PMI kvalifikácia a PRINCE2 kvalifikácia sú v podstate odlišné - hoci sú vel'mi komplementárne.“

Jeden z akceptovaných štandardov pre kategorizáciu rôznych typov skúšok je Bloomova taxonómia. Aby sme ich mohli navzájom posúdit', je nevyhnutné ohodnotit' každú kvalifikáciu vzhl'adom na úrovne uvedené v taxonómii.

K porovnaniu PRINCE2 s PMI (PMBoK) uviedol Alan Harpham nasledovné [3]: „Materiály porovnávajúce PMBoK a PRINCE2 dokazujú, že PRINCE2 vo všeobecnosti zodpovedá zásadám projektového manažmentu v PMBoK. Sú to skôr komplementárne ako protikladné dokumenty. Má význam na to upozornit', hoci PRINCE2 je metodológia - proces pre manažovanie jednotlivých projektov; PMBoK je zoskupenie všeobecných poznatkov o projektovom manažmente.”

Metódy PRINCE2 a MSP boli vytvorené organizáciou OGC. Ked’že ich tvorcovia sú z jednej organizácie, považujeme za vhodné identifikovat' oblasti, na ktoré sú jednotlivé metódy zamerané, prípadne uviest' oblasti, v ktorých sa metódy prekrývajú.

Tony Kippenberger v tejto súvislosti vyjadril presvedčenie [3]: "Pokial' sme si vedomí, neexistujú žiadne odporučenia, týkajúce sa prekrývania MSP a PRINCE2, ale zámerom OGC je zlepšit' ich prepojenie." Tento ciel' bol sledovaný aj v novom vydaní PRINCE2 (2009). Nové verzie MSP (2007) a PRINCE2 (2009) už využívajú spoločný slovník vytvorený OGC.

Analýzou metód PRINCE2 a MSP môžeme pozorovat' dôraz metódy PRINCE2 na Manažment konfigurácie a Riadenie zmien. Naopak MSP je zamerané na Víziu, Manažment zúčastnených strán, Manažment realizácie prínosov a Manažment blueprintu, zatial čo PRINCE2 je týchto oblastiach slabšie.

Andy Taylor k jednotlivým komponentom PRINCE2 a MSP uviedol [3]:

„Pripomenul by som, že MSP nie je slabá v Manažmente konfigurácie a Riadení zmien, ale je vel'mi odlišná od PRINCE2, pretože je potrebná na manažovanie dodania programu. Ten istý argument môže byt' použitý pre komponenty PRINCE2.“

Z účelu metód by sa zdalo jasné, že metóda PRINCE2 je určená pre projekty a MSP pre programy, ale $\mathrm{v}$ prostredí niektorých organizácií sa toto chápanie niekedy ignoruje. Dokonca by sme mohli vyjadrit' domnienku, že prevažujúca znalost' metódy PRINCE2 vedie organizácie k tomu, aby považovali programy za vel'ké projekty a pokúšali sa ich riadit' metódami PRINCE2. Z tohto pohl'adu sa zdá dôležité uviest' argumenty, prečo PRINCE2 nie je vhodná pre programový manažment? Je tomu tak preto, lebo PRINCE2 sa venuje oblastiam ako Vízia, Manažment zúčastnených strán, Manažment realizácie prínosov a Manažment blueprintu vel'mi slabo alebo skoro vôbec?

Naopak metóda MSP sa z pohl'adu manuálov pre jednotlivé metódy venuje otázkam Manažmentu konfigurácie a Riadenia zmien vel'mi málo v porovnaní s metódou PRINCE2. Andy Taylor uviedol [3]: „MSP sa zaoberá Riadením zmien a Manažmentom konfigurácie vel'mi stručne, pretože pre programy nie sú tak dôležité. Na druhej strane PRINCE2 sa nezaoberá efektívne s oblast’ami ako Vízia, Manažment zúčastnených strán, Manažment realizácie prínosov a Manažment blueprintu, pretože si to projekty nevyžadujú, zatial' čo existujú kritické oblasti (najmä Manažment prínosov) pre programy.

Programy nie sú vel'ké projekty a vyžadujú nielen odlišné procesy a sústredenie na odlišné veci, ale tiež vyžadujú odlišné poznatky a kompetencie v manažéroch.

Existuje viacero článkov a kníh, ktoré sa zaoberajú touto otázkou - všetky upozorňujú na to, že rozdiel medzi projektmi a programami je vel'ký a musia byt' manažované odlišne.“

Niektoré z charakteristík projektov a programov uvádzame v tab. č. 1 . 
Predtým, ako sa začne každý projekt v portfóliu projektov programu, existuje projektový podnikatel'ský prípad, iné je to však s podnikatel'ským prípadom na programovej úrovni.

Podnikatel'ský prípad je odvodený z blueprintu, ale je náročné ho vytvorit', pretože programový manažér nemôže vediet' dost' o výsledkoch vel'kého programu, aby vytvoril dobrý podnikatel'ský prípad.

Andy Taylor v súvislosti s programovým podnikatel'ským prípadom poznamenal [3]: „Programový podnikatel'ský prípad je celý o odôvodnení (obyčajne vel'kých) výdavkov spojených s realizáciou programu. Je pravdepodobne slabšie definovaný na začiatku a $\mathrm{s}$ postupom programu sa stáva rozvinutejším. Nie je to statický dokument (vo väčšej miere ako projektový podnikatel'ský prípad).

Odhadujem, že na konci dňa bude požiadavka na dostatok informácií a detailov, pretože tvorcovia rozhodnutí o investíciách potrebujú vykonat' rozhodnutie o začatí programu. Toto bude evidentne odlišné od organizácie k organizácii.

Obsah podnikatel'ského prípadu je zretel'ne a jasne zameraný na odôvodnenie programu. Dôležité sú prínosy, ktoré pribudnú z programu. Toto je skutočné odôvodnenie, pokial' je vyvážené vzhl'adom na očakávané náklady.

Ako mi niekto nedávno navrhol, spotrebovat' 500 miliónov na program, ktorý prinesie úžitok 50 miliónov je nezmyslom, pokial' neexistuje na pozadí iné vel'mi dobré odôvodnenie.

Podnikatel'ský prípad by mal byt' dokumentom, ktorý tvorcovia rozhodnutí o investovaní (skupina sponzorov) môžu použit' na odôvodnenie ich nákladov hoci nezabúdajú na fakt, že majú vždy možnost' zastavenia programu pri d'alšom ukončení kontroly tranže alebo inej vhodnej príležitosti, ak sa ukáže, že podnikatel'ský prípad už nie je „opodstatnený“ - čokol'vek to môže znamenat' v relevantných okolnostiach programu."

\begin{tabular}{|c|c|c|}
\hline & Projekt & Program \\
\hline Zameranie & Jednoduchý ciel' & Podnikatel'ská stratégia \\
\hline Rozsah & Úzky & Široký, naprieč rôznymi funkciami \\
\hline Prínosy & $\begin{array}{c}\text { Determinované vopred, vyplynú z } \\
\text { dokončenia }\end{array}$ & $\begin{array}{l}\text { Používané na tvorbu rozhodnutí, } \\
\text { pribúdajú postupne počas programu }\end{array}$ \\
\hline Realizačné výstupy & Málo, jasne definované & $\begin{array}{l}\text { Vel'a, vel'a na začiatku } \\
\text { nedefinovaných }\end{array}$ \\
\hline Časové merítko & Jasne definované & Vol'ne definované \\
\hline Náhl'ad zmeny & Vyhýbame sa & Považovaný za nevyhnutný \\
\hline Úspech & Čas, rozpočet, špecifikácia & $\begin{array}{l}\text { Cashflow, misia, návratnost' } \\
\text { investícii }\end{array}$ \\
\hline Plán & Špecifický, detailný, ohraničený & Vysokoúrovňový a rozvíjajúci sa \\
\hline
\end{tabular}

Tab. č. 1. Vybrané charakteristiky projektov a programov, prebrané a upravené z [4]

\section{Akreditácia organizácií v metódach PRINCE2 a MSP}

Organizácie, ktoré chcú využívat' tieto metódy nepotrebujú žiadne oprávnenie na ich používanie a súčasne majú právo verejne tvrdit', že spomenuté metódy využívajú.

Tony Kippenberger v tejto súvislosti uviedol [3]: „PRINCE2 metóda je vo verejnej sfére a organizácie ju môžu používat' pre svoje vlastné účely bez poplatkov. Organizácie, ktoré používajú PRINCE2 môžu povedat', že je to to, čo robia.““

Na druhej strane tieto organizácie nemôžu poskytnút’ žiadny doklad o tom, že majú odbornost' v používaní PRINCE2. Táto metóda sa dnes využíva tak často, že nemožno 
samotný fakt, že ju niekto používa pokladat' za rozhodujúci. Pre tento účel vytvorilo OGC tzv. PRINCE2 Maturity Model (P2MM), ktorý umožňuje určit' úroveň odbornosti organizácie vo využívaní metódy PRINCE2 a nechat' si ho nezávislou stranou potvrdit'.

PRINCE2 Maturity Model (P2MM) a širší Project Management Maturity Model (PMMM) vytvoril Office of Government Commerce (OGC)

APM Group (akreditačný, registračný a skúšobný certifikovaný orgán pre OGC), ktorý je partnerom OGC, využil OGC modely a vyvinul proces hodnotenia, ktorý determinuje úroveň vyspelosti organizácie v PRINCE2 alebo v programovom a projektovom manažmente [3].

\section{Záver}

Ako bolo uvedené v [1], PRINCE2 bolo odvodené z PROMPT II, teda metódy, ktorú vyvinuli v spoločnosti Simpact, jej autormi sú bývalí manažéri z IBM v Spojenom král'ovstve. Pomerne dlhú dobu po vytvorení bola zameraná na projektový manažment IT projektov. K zmene metódy na všeobecnú metódu pre projektový manažment došlo až v roku 1996. Podobným procesom revízií prešla aj metóda MSP. Jedným z ciel’ov spomenutých zmien v metódach bola snaha prispôsobit' ich čo najširšiemu spektru záujmových strán.

Pri vývoji obidvoch metód sa snaží OGC spolupracovat' s čo najširším spektrom expertov. Títo experti reprezentujú širokú škálu názorov a poznatkov o tom, čo predstavuje najsprávnejší postup. Tieto odlišné prístupy sú subjektom rozsiahlych posudkov a procesov zlučovania do konečnej podoby metód. Práve z dôvodu neustálych zmien v postoji k tomu, čo predstavuje najsprávnejší postup, sú metódy podrobované zmenám. Tento ciel' mali aj posledné vydania metód. Jedným zo sledovaných ciel'ov bolo použitie jednotného slovníka pre obe metódy.

\section{Literatúra a použité zdroje:}

1. $\quad$ http://ks.utc.sk/casopis/pdf/I2009/bombala2.pdf

2. $\quad$ http://ks.utc.sk/casopis/pdf/III2009/bombala.pdf

3. www.pm4success.com

4. http://www.ogc.gov.uk/documents/Skills_Framework_Document_v1.pdf

5. www.orsoc.org.uk/region/study/infor/PS SIG 10-04-2003.ppt

6. http://www.buzzle.com/articles/understanding-msp-programme-management.html

7. http://www.12manage.com/methods_ogc_msp.html

8. Office of Government Commerce: Managing Successful Projects with PRINCE2, London, 2005, ISBN 9780113309467 